\title{
К ЮБИЛЕЮ АРХЕОЛОГА РИММЫ ДМИТРИЕВНЫ ГОЛДИНОЙ
}

\section{(C) 2021 г. О.М. Мельникова}

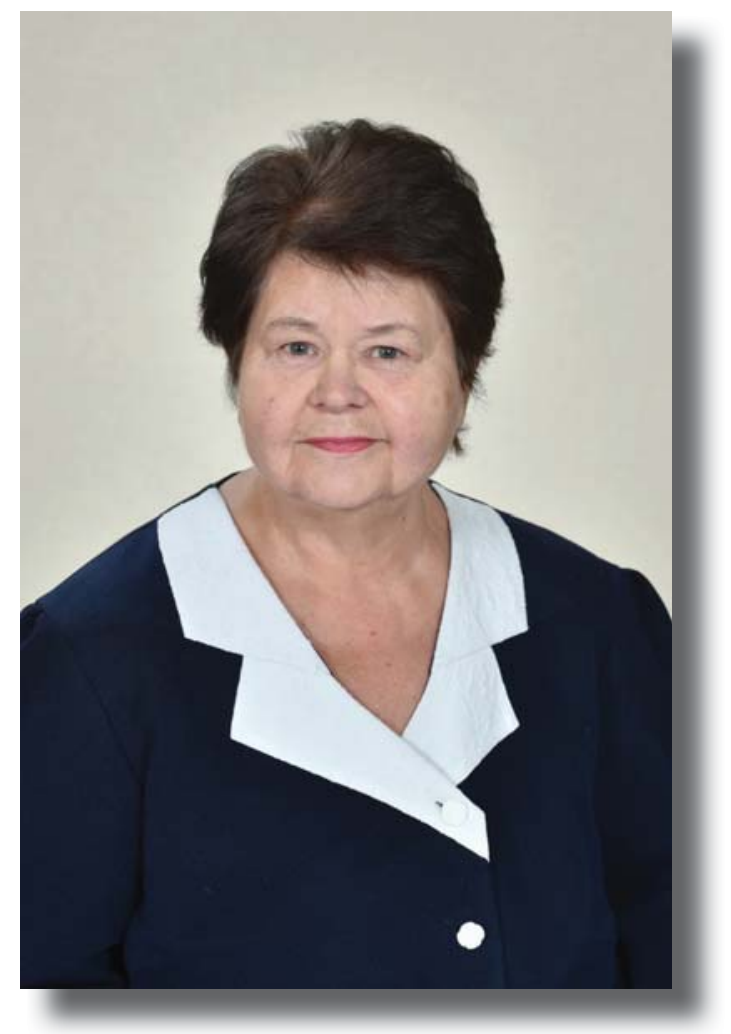

В статье оценивается научная, педагогическая, общественная деятельность Заслуженного работника высшей школы, лауреата Государственной премии Удмуртской Республики, доктора исторических наук профессора кафедры истории Удмуртии, археологии и этнологии, директора Института истории и культуры народов Приуралья Удмуртского государственного университета Риммы Дмитриевны Голдиной.

Ключевые слова: юбилей археолога, Р.Д. Голдина, научный вклад.

\section{THE ANNIVERSARY OF THE ARCHAEOLOGIST RIMMA DMITRIEVNA GOLDINA}

\section{O.M. Melnikova}

The paper evaluates the scientific, pedagogical, social activities of the Honorary Figure of Higher Education, laureate of the State Prize of the Udmurt Republic, Doctor of Historical Sciences, Professor of the Department of History of Udmurtia, Archeology and Ethnology, Director of the Institute of History and Culture of the Peoples of the Urals of the Udmurt State University Rimma Dmitrievna Goldina.

Keywords: archaeologist's anniversary, R.D. Goldina, scientific contribution.

Статус научной дисциплины в обществе в немалой степени зависит от подвижничества ученых, чья деятельность определяет содержание и уровень научного знания, его включенность в широкие междисциплинарные связи и разнообразные социальные практики. Эти личности влияют на ключевые направле- ния научного поиска, определяют оптимальные организационные формы деятельности научного сообщества, которые затем воспроизводятся в следующих поколениях. Они определяют не только стандарты профессионализма в науке, но и непосредственно задают этические нормы жизни в профессии. Быть 
современником творцов исследовательских идей, а тем более учениками таких ученых - настоящая жизненная удача. В ряду таких ярких личностей - археолог, доктор исторических наук, профессор Удмуртского государственного университета Римма Дмитриевна Голдина. В ноябре 2021 г. она отмечает свой юбилей.

Ее личная биография неразрывно вплетена в историю уральской археологии (Мельникова, 2006). Став своеобразным мостиком между двумя научными археологическими школами - Пермской О.Н. Бадера, где она впитала основы археологической науки, и Свердловской В.Ф. Генинга, где она сформировалась исследовательски, Римма Дмитриевна смогла определить и найти свой собственный путь в археологии (Голдина, 2002, с. 16-55).

В каждый период развития науки ее лицо определяют интеллектуальные лидеры, их исследовательские идеи становятся основанием научных взглядов, характеризующих время, в котором они творят. Поиск и выявление значительного круга археологических памятников от каменного века до нового времени на территории Удмуртии, Кировской и Пермской областей, создание на их основе источниковой базы, хронологические изыскания - вот первые самостоятельные шаги, предпринятые исследователем в начале работы в Удмуртском университете. Вслед за этими серьезными основаниями - вопросы этнической истории финно-пермских народов, авторская историко-археологическая концепция формирования и развития традиционных этносов Приуралья, использование широких междисциплинарных связей для изучения сложных процессов этнокультурных взаимодействий культур и этносов, исторические процессы эпохи великого переселения народов в Приуралье - вот далеко неполный перечень исследовательских интересов Р.Д. Голдиной (Список научных трудов, 2002 , с. 55-66). Движение к их зарождению, сложный поиск ответов археолога на поставленные вопросы, поиск инструментов для их разрешения, преодоление организационных трудностей изложены Риммой Дмитриевной в целой серии работ, посвященных осмыслению процессов развития урало-поволжской археологии (Голдина, 1996; Голдина, 2002, с. 16-55; Голдина, 2014). Археолог предстает в них как историк своей науки, позволяя читателю увидеть непростые процессы повседневного бытия науки, запечатлеть образы выдающихся ученых и исследователей, чьи имена малоизвестны широкому читателю.

Уроки личного опыта Р.Д. Голдина с готовностью передает уже нескольким поколениям студентов Удмуртского государственного университета, многие десятилетия осваивавших азы археологии в университетских стенах и в поле во время археологической практики в созданной ею Камско-Вятской археологической экспедиции. Организационный дар ученого воплотился в создании разных учебных и научных институций УдГУ: кабинете археологии, лаборатории археологических исследований, кафедре археологии и истории первобытного общества, музее древней и средневековой истории Прикамья, Институте истории и культуры народов Приуралья, диссертационном совете по защите диссертаций. Эпоха Риммы Дмитриевны на посту декана исторического факультета Удмуртского университета стала одной из самых заметных в его 90-летней истории.

Более тридцати ее учеников получили ученые степени кандидата исторических наук, а для троих она стала строгим и взыскательным научным консультантом при выполнении докторских диссертаций. Свыше 200 диссертаций было защищено учеными из научных, музейных, образовательных учреждений Ижевска, Казани, Перми, Сыктывкара, Йошкар-Олы, Самары, Саранска, Пензы, Сургута, Екатеринбурга, Челябинска, Нижнего Тагила, Кирова и других городов в диссертационном совете, председателем которого Р.Д. Голдина являлась с 1993 по 2020 г. Среди них 25 докторов исторических наук - организаторов науки в различных центрах России.

Почти четыре сотни научных статей, свыше 20 монографий содержат размышления исследователя о сложных исторических процессах, исследуемых посредством археологического источника. Они широко востребованы в археологическом сообществе. Ее научные концепции находят своих приверженцев, в своих исследованиях убеждающихся в правоте исследовательской мысли Р.Д. Голдиной. Научные оппоненты идей ученого побуждают ее к поиску новых аргументов в пользу своих 
представлений об исследуемых проблемах. Аспиранты учатся строгости научных построений и умению аргументировать и отстаивать свою исследовательскую позицию.

Р.Д. Голдина - яркая творческая личность, наш коллега и учитель встречает свой 80-летний юбилей впечатляюще: благодаря ей значительно удревнена история Удмур- тии, создана мощная источниковедческая база для изучения разных исторических эпох, в Удмуртском государственном университете работают ее ученики, воспринявшие и развивающие традиции созданной ею археологической научной школы.

С днем рождения, дорогая Римма Дмитриевна!

\section{ЛИТЕРАТУРА}

Голдина Р.Д. Силуэты растаявших веков. Ижевск: Удмуртия, 1996. 213 с.

Голдина Р.Д. Мой путь в археологию // Исследовательские традиции в археологии Прикамья / Материалы и исследования Камско-Вятской археологической экспедиции. Т. 4./ Ред. О.М. Мельникова и др. Ижевск: УдГУ, 2002. С. 16-55.

Голдина (Вотинцева) Р.Д. Большая Соснова - большая любовь. Ижевск: Администрация Большесосновского р-на Пермского края, 2014. 342 с.

Голдина Р.Д., Красноперов А.А. Ныргындинский I могильник II-III вв. на Средней Каме / Материалы и исследования Камско-Вятской археологической экспедиции. Т. 22. Ижевск: Удмуртский университет, 2012. $364 \mathrm{c}$.

Мельникова О.М. Научная археологическая школа Р.Д. Голдиной в Удмуртском университете / Материалы и исследования Камско-Вятской археологической экспедиции. Т. 15. Ижевск: б/и, 2006. 142 с.

Список научных трудов Р.Д. Голдиной // Исследовательские традиции в археологии Прикамья. Материалы и исследования Камско-Вятской археологической экспедиции. Т.4. Ижевск: УдГУ. 2002. С. 55-65.

\section{Информация об авторе:}

Мельникова Ольга Михайловна, доктор исторических наук, доцент, заведующая кафедрой истории Удмуртии, археологии и этнологии, Удмуртский государственный университет (г. Ижевск, Россия); superlvovich2012@yandex.ru

\section{REFERENCES}

Goldina, R. D. 1996. Siluety rastayavshikh vekov (Silhouettes of Melted Centuries). Izhevsk: "Udmurtiia" Publ. (in Russian).

Goldina, R. D. 2002. In Mel'nikova, O. M. et. al. (eds.). Issledovatel'skie traditsii v arkheologii Prikam'ia (Research Traditions in the Archaeology of the Kama Region). Series: Materialy i issledovaniia Kamsko-Viatskoi arkheologicheskoi ekspeditsii (Proceedings and Research of the Kama-Vyatka Archaeological Expedition) 4. Izhevsk: Udmurt State University, 16-55 (in Russian).

Goldina (Votintseva), R. D. 2014. Bol'shaia Sosnova - bol'shaia liubov'(Bol shaya Sosnova is Great Love). Izhevsk: s. ed. (in Russian).

Goldina, R. D., Krasnopeorov, A. A. 2012. Nyrgyndinskii I mogil'nik II-III vv. na Srednei Kame (Nyrgynda I Burial Ground from $2^{\text {nd }}-3^{\text {rd }}$ Centuries in the Middle Kama Area). Series: Materialy i issledovaniia Kamsko-Viatskoi arkheologicheskoi ekspeditsii (Proceedings and Research of the Kama-VyatkaArchaeological Expedition) 22. Izhevsk: Udmurt State University (in Russian).

Mel'nikova, O. M. 2006. Nauchnaia arkheologicheskaia shkola R. D. Goldinoi v Udmurtskom universitete (R. D. Goldina Scientific Archaeological School in Udmurt University). Series: Materialy i issledovaniia Kamsko-Viatskoi arkheologicheskoi ekspeditsii (Proceedings and Research of the Kama-Vyatka Archaeological Expedition) 15. Izhevsk: s. ed. (in Russian).

2002. Spisok nauchnykh trudov R.D. Goldinoi (List of Scientific Works by R. D. Goldina) In Mel'nikova, O. M. et. al. (eds.). Issledovatel'skie traditsii v arkheologii Prikam'ia (Research Traditions in the Archaeology of the Kama Region). Series: Materialy i issledovaniia Kamsko-Viatskoi arkheologicheskoi ekspeditsii (Proceedings and Research of the Kama-Vyatka Archaeological Expedition) 4. Izhevsk: Udmurt State University, 55-65 (in Russian).

\section{About the Author:}

Melnikova Olga M. Doctor of Historical Sciences. Udmurt State University, Institute of History and Sociology. Universitetskaya St., 1, building 2, Izhevsk, 426034, Russian Federation; superlvovich2012@yandex.ru 